\title{
Cloning and regulatory analysis of groESL operon from halophilic lactic acid bacterium Tetragenococcus halophila
}

\section{Fukuda, Daisuke}

Laboratory of Microbial technology, Division of Microbial Science and Technology, Department of Bioscience and Biotechnology, Graduate School of Bioresource and Bioenvironmental Sciences, Kyushu University

\section{Watanabe, Maki}

Laboratory of Microbial technology, Division of Microbial Science and Technology, Department of Bioscience and Biotechnology, Graduate School of Bioresource and Bioenvironmental Sciences, Kyushu University

Aso, Yuji

Laboratory of Microbial technology, Division of Microbial Science and Technology, Department of Bioscience and Biotechnology, Graduate School of Bioresource and Bioenvironmental Sciences, Kyushu University

\section{Sonomoto, Kenji}

Laboratory of Microbial technology, Division of Microbial Science and Technology, Department of Bioscience and Biotechnology, Graduate School of Bioresource and Bioenvironmental Sciences, Kyushu University

他

https://doi.org/10.5109/24449

出版情報: 九州大学大学院農学研究院紀要. 46 (2)，pp.353-365，2002-02-28. Kyushu University バージョン：

権利関係 : 


\title{
Cloning and regulatory analysis of groESL operon from halophilic lactic acid bacterium Tetragenococcus halophila
}

\author{
Daisuke FUKUDA, Maki WATANABE, Yuji ASO, Kenji SONOMOTO* \\ and Ayaaki ISHIZAKI
}

\author{
Laboratory of Microbial Technology, Division of Microbial Science and Technology, Department of \\ Bioscience and Biotechnology, Faculty of Agriculture, Graduate School, Kyushu \\ University, 6-10-1, Hakozaki, Higashi-ku, Fukuoka 812-8581, Japan \\ (Received October 31, 2001 and accepted November 20, 2001)
}

\begin{abstract}
The groESL operon of a halophilic lactic acid bacterium, Tetragenococcus halophila, was cloned and sequenced. The nucleotide sequence of 2,853-bp revealed the presence of two open reading frames corresponding to the $g r o E S$ and $g r o E L$ genes. The molecular masses of GroES and GroEL proteins were calculated to be 10,153 and $56,893 \mathrm{Da}$, respectively. They showed high similarities with the corresponding proteins of other lactic acid bacteria such as Lactobacillus zeae. CIRCE (Controlling Inverted Repeat of Chaperone Expression) element was identified in the upstream region of groES. Northern blot hybridization has demonstrated that the groES and groEL genes are transcribed as a bicistronic mRNA of $2.2 \mathrm{~kb}$, and transcriptionally induced 3.8 -fold by heat shock $\left(45^{\circ} \mathrm{C}\right)$ for $30 \mathrm{~min}$. The amount of groESL mRNA was also increased about 4 -fold by high $\mathrm{NaCl}$ condition. Primer extension analysis indicated that the expression of $T$. halophila groESL was governed by the constitutive promoter both under normal and stress conditions.
\end{abstract}

\section{INTRODUCTION}

Heat shock proteins (HSPs) are temporarily overexpressed when cells are exposed to high temperature, high salinity and other various kinds of environmental stresses (Lindquist and Craig, 1988). HSPs are widely contributed to protect cells from lethal effect of stresses as molecular chaperones involved in maturation of newly synthesized polypeptides and promotion of refolding and degradation of denatured proteins (Hartl, 1996) .

In Escherichia coli, about 20 heat shock proteins are known (Gross et al., 1991), and two major HSPs families, DnaK and GroESL have been extensively characterized (Liberek et al., 1991). Molecular chaperonin proteins of GroES and GroEL are essential for growth of $E$. coli even under optimum growth conditions, and enhanced synthesis of GroESL was observed by exogenous environmental stresses (Langer et al., 1992). The transcription of heat shock genes in $E$. coli is mainly mediated by $\sigma^{32}$-dependent promoters (Cowing $e t$ $a l ., 1985)$. However, in $B$. subtilis, some heat shock genes possess an regulatory inverted repeat sequence, termed CIRCE, in the region around vegetative promoter (Zuber and Schumann, 1994). Studies on other variety of bacteria genera have also demonstrated increased synthesis of GroES and GroEL following exposure to heat shock, low $\mathrm{pH}$, ethanol and salt, suggesting a role for these proteins in the adaptation against general

\footnotetext{
* Corresponding author (E-mail: sonomoto@agr.kyushu-u.ac.jp)
} 
stress (Fujita et al., 1998; Homuth et al., 2000). In Lactococcus lactis, GroEL and GroES showed similar temporal induction patterns of $\mathrm{NaCl}$ stress, resembling those of heat shock (Kilstrup et al., 1997). This has indicated that the GroESL molecular chaperone system plays an important role to adapt to salinity conditions as well as heat shock.

Tetragenococcus halophila (formerly known as Pediococcus halophilus) is a moderately halophilic Gram-positive lactic acid bacterium (LAB) used for brewing of Japanese soy sauce. Based on $16 \mathrm{~S}$ rDNA sequence studies, this bacterium shows close phylogenetic relationship to enterococci and lactobacilli (Collins et al., 1990). Unlike these genera of LAB, T. halophila can tolerate high salt concentrations (up to $26 \%$ $\mathrm{NaCl}$ ), and grows optimally in media containing 0.5 to $3.0 \mathrm{M}$ of $\mathrm{NaCl}$ (Rölling and Van Verserveld, 1996). When cultivated in a high salt concentration medium, T. halophila is known to accumulate intracellularly not only $\mathrm{Na}^{+}$but also much amount of $\mathrm{K}^{+}$and several organic compounds as compatible solutes (Robert et al., 2000). We have much interest in the functions and the expression behavior of $T$. halophila GroESL under the condition of high intracellular osmotic pressure and increased hydrophobic interactions in the protein structure. In this paper, we describe the cloning, structural characterization and transcriptional analysis of the groESL operon of $T$. halophila. Data on the character of $T$. halophila GroESL contributes to better understanding of its adaptation mechanism to environmental stresses, especially against high salinity.

\section{MATERIALS AND METHODS}

\section{Bacterial strains and growth conditions}

T. halophila JCM5888 (ATCC33315 $5^{\mathrm{T}}$ ) used in this study, was grown at $30^{\circ} \mathrm{C}$ in MRS medium (Oxoid, Hampshire, England) containing $1 \mathrm{M} \mathrm{NaCl}$. The medium was adjusted to pH 7.5 before sterilization. Escherichia coli JM109 (Toyobo, Osaka, Japan) was grown at $37^{\circ} \mathrm{C}$ with shaking in Luria-Bertani broth. When the growing was appropriate for clonal selection, X-gal (5-bromo-4-isopropyl- $\beta$-D-4-chloro-3-indol- $\beta$-D-galactopyranoside), IPTG (isopropyl 1 -thio- $\beta$-D-galactoside) and ampicillin were added at concentrations of $50,40,20 \mathrm{mg} /$, respectively.

\section{DNA isolation and manipulation}

T. halophila chromosomal DNA was isolated by applying a combination of the two methods as described previously (Marmur, 1961; Berns and Thomas, 1965). Plasmid DNA, pUC18 vector, used for cloning of T. halophila groESL operon, was purified from E. coli with Mag extractor plasmid extraction kit (Toyobo). Restriction endonuclease digestions, analyses and ligations were performed according to the methods of Sambrook et al. E. coli competent cells for electroporation were prepared according to the protocol recommended for the Gene Pulser apparatus (Bio-Rad, Hercules, CA, USA). Southern hybridization with nucleotide probes was performed by using the AlkPhos labeling system (Amersham Pharmacia Biotech, Uppsala, Sweden) according to the manufacture's protocol.

\section{Cloning of T. halophila groESL operon}

Two degenerated oligonucleotides (groel-TS1 and groel-TA1) used as PCR primers were designed from GroEL conserved region of other Gram-positive bacteria (Table 1). 
PCR was performed in a $100-\mu \mathrm{l}$ volume containing $1 \mu \mathrm{g}$ genomic DNA, $50 \mathrm{mM} \mathrm{KCl}, 10 \mathrm{mM}$ Tris- $\mathrm{HCl}$ ( $\mathrm{pH} 9.0$ ), 0.1\% Triton X-100, $1.5 \mathrm{mM} \mathrm{MgCl}_{2}, 0.2 \mathrm{mM}$ of each dNTPs, $100 \mathrm{pmol}$ of

Table 1. Oligonucleotide primers used in this study.

\begin{tabular}{|c|c|c|}
\hline Names & Sequences & Notes \\
\hline groel-TS1 & 5-G(T/C)GAAGATTTGAAGAACGTTAC $-3^{\prime}$ & $\begin{array}{l}\text { The degenerative oligonucleotide primer } \\
\text { corresponding to the } 287 \text { to } 308 \text { of the } T \text {. } \\
\text { halophila groEL gene. }\end{array}$ \\
\hline groel-'TA1 & 5'-CAGTTTCAGTAGC(A/G)GCACCAAC-3' & $\begin{array}{l}\text { The degenerative oligonucleotide primer } \\
\text { corresponding to the } 1123 \text { to } 1144 \text { of the } \\
\text { T. halophila groEL gene. }\end{array}$ \\
\hline gros-IS1 & 5'-CCTTCAACGACATCCAATTCTG-3' & $\begin{array}{l}\text { The oligonucleotide primer corresponding } \\
\text { to the } 536 \text { to } 558 \text { of the } T \text {. halophila } \\
\text { groEL gene. }\end{array}$ \\
\hline gros-IA1 & 5'GGTAACGGATAATGAAAAAATGGAAGC - 3' & $\begin{array}{l}\text { The oligonucleotide primer corresponding } \\
\text { to the } 594 \text { to } 620 \text { of the } T \text {. halophila } \\
\text { groEL gene. }\end{array}$ \\
\hline grol-IS2 & 5-GACGGCCGCCAAATCCAGGA-3' & $\begin{array}{l}\text { The oligonucleotide primer corresponding } \\
\text { to the } 816 \text { to } 835 \text { of the } T \text {. halophila } \\
\text { groEL gene. }\end{array}$ \\
\hline grol-IA2 & 5-GACATCGCTGTATTGACTGGTGC-3' & $\begin{array}{l}\text { The oligonucleotide primer corresponding } \\
\text { to the } 853 \text { to } 875 \text { of the } T \text {. halophila } \\
\text { groEL gene. }\end{array}$ \\
\hline
\end{tabular}

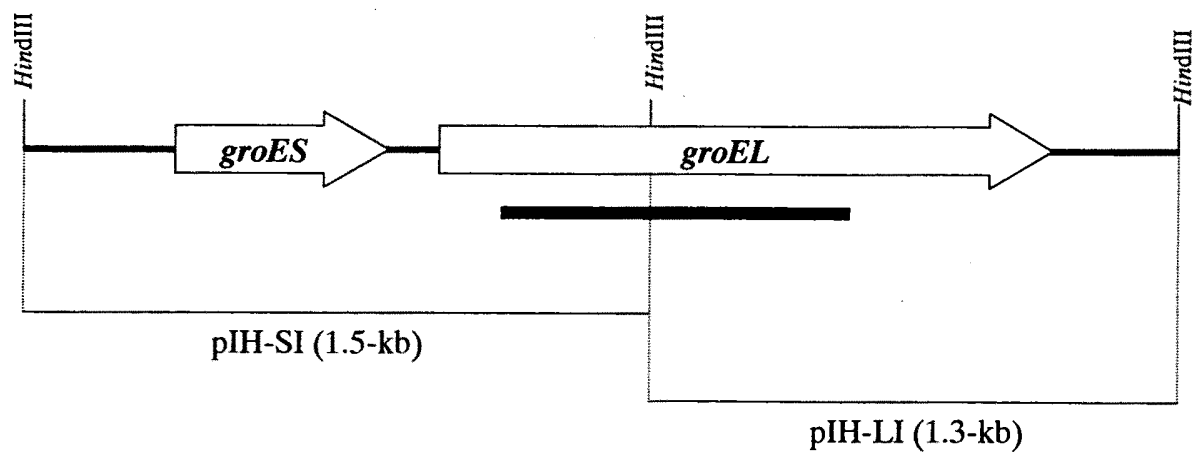

Fig. 1. Genetic organization and restriction map of the T. halophila groESL.

The originally amplified region by priming with groel-TA1 and groel-TS1 oligonucleotides is shown with a bold box. Three HindIII sites which were used in the inverse PCR are also shown. Two bold bar correspond to the coding region of groES and groEL. 
each primer and $5 \mathrm{U}$ of $\mathrm{Taq}$ polymerase. Amplification was carried out for 30 cycles (denaturation at $95^{\circ} \mathrm{C}$ for $1 \mathrm{~min}$, annealing at $50^{\circ} \mathrm{C}$ for $30 \mathrm{sec}$, and polymerization at $72^{\circ} \mathrm{C}$ for $1 \mathrm{~min})$. Amplified fragment of an expected size $(0.9-\mathrm{kb})$ was labeled with AlkPhos Direct System (Amersham Pharmacia Biotech) and used as a probe to screen a $T$. halophila genomic library. The 1.5--kb (pIH-SI) and 1.3-kb (pIH-LI) fragments (Fig. 1), which generated a strong hybridization signal with the probe, were cloned by "inverse PCR" as follows (Innis et al., 1990). T. halophila chromosomal DNA was digested completely with Hind III and religated for use as the template. PCR reaction with gros-IA1 and gros-IS1 (Table 1) yielded a 1.5-kb amplified fragment. 1.3-kb amplicon was also obtained by same method with primers grol-IA2 and grol-IS2 (Table 1). Inverse PCR was performed with KOD DNA polymerase (Toyobo), which increased polymerization fidelity. The generated fragment was cloned into $S m a I$ site of pUC18 and transformed into $E$. coli JM109. The cloned fragments were sequenced with ALF express automated DNA sequencer (Amersham Pharmacia Biotech) and analyzed with the DNASIS program (Hitachi Software Engineering, Tokyo, Japan) and GENETYX-WIN (Software Development, Tokyo, Japan).

\section{Comparison of deduced amino acid sequence and phylogenetic analysis of $T$. halophila GroESL}

The amino acid sequence similarities of GroES and GroEL were investigated using BLAST service (Altschul et al., 1997). The multiple alignments of the GroEL amino acid sequences were performed by the program ClustalW and were adjusted manually (Thompson et al., 1994). The phylogenetic tree based on the NJ (Neighbor-joining) method was constructed by Treeview (ver. 1.6) (Saitou and Nei, 1985). Accession numbers of other sequences used for the analysis are as follows; Bacillus subtilis groEL, D10972 (Li and Wong, 1992); Clostridium acetobutylicum groEL, M74572 (Nerberhaus and Bahl, 1992); E. coli groEL, X07850 (Hemmingsen et al., 1988); Lactobacillus helveticus groEL, AF031929 (Broadbent, 1998); Lactobacillus johnsonii groEL, AF214488 (Walker et al., 1999); Lactococcus lactis groEL, AY029215 (Kim and Batt, 1993); Neisseria gonorrhoeae groEL, U64996 (Tauschek et al., 1997); Listeria monocytogenes groEL, AF335323 (Gahan et al., 2001); Pseudomonas aeruginosa groEL, S77424 (Sipos et al., 1991); Porphylomonas gingivalis pggroEL, D17398 (Hotokezaka et al., 1994); Staphylococcus aureus hsp60, D14711 (Ohta et al., 1993); Streptococcus pneumoniae groEL, AF117741 (Kim et al., 2001); Thermus aquaticus groEL, U29483 (Mikulik and Benada, 1993); Vibrio vulnificus groEL, AY017169 (Wong et al., 2001).

\section{Nucleotide sequence accession number}

The nucleotide sequence reported in this article has been assigned GenBank accession number AB073399.

\section{Northern blot hybridization}

Total RNA was isolated from T. halophila cells using RNeasy Total RNA kit (Qiagen,

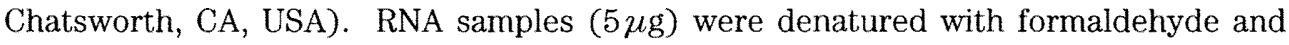
electrophoresed at $50 \mathrm{~V}$ for $1 \mathrm{~h}$ on a $1.5 \%$ agarose gel containing $20 \mathrm{mM}$ MOPS (morpholine propane sulfonic acid) buffer, $\mathrm{pH} 8.0$ and $2.2 \mathrm{M}$ formaldehyde. After electrophoresis, 
capillary transfer to a nylon membrane (Hybond- $\mathrm{N}^{+}$, Amersham Pharmacia Biotech) was carried out in $20 \times \mathrm{SSC}(1 \times \mathrm{SSC} ; 0.15 \mathrm{M} \mathrm{NaCl}, 15 \mathrm{mM}$ trisodium citrate, $\mathrm{pH} 7.0)$. The PCR-generated probe, used in cloning the T. halophila groESL operon described above, was labeled with ${ }^{32} \mathrm{P}$-dCTP. Northern blot hybridization was carried out at $42^{\circ} \mathrm{C}$ for $12 \mathrm{~h}$. The relative concentration of groESL transcripts was estimated by autoradiograph densitometry with a BAS 2000 Bio-Imaging Analyzer system (Fuji Photo Film, Tokyo, Japan).

\section{Slot-blot hybridization}

Slot-blot hybridization method is less prone to pipetting errors compared to the Northern blot hybridization, being more relevant in terms of exact quantification. Five microgram of alkaline-denatured total RNA was transferred to Zeta Probe blotting membranes (Bio-Rad) with a Bio-Dot SF microfiltration apparatus (Bio-Rad) as specific manufacturer, and treated with UV cross link. Prehybridization and hybridization were carried out by the same method as Northern hybridization described above. Relative amounts of the transcript were also quantified by densitometric analysis using BAS 2000 Bio-Imaging Analyzer system (Fuji Photo Film).

\section{Primer extension analysis}

The transcriptional initiation site was determined by primer extension analysis using the ${ }^{32}$ P-labeled primer Gro-PE10 (5'-TAC GTC CTG GAC CGA CAG C-3') (Asubel et al., 1987), which complements nucleotides 131 to 149 of the groES gene. Total RNA was isolated as described above, and reverse transcription was performed with AMV Reverse Transcription System (Promega, Madison, WI, USA). Nucleic acids were precipitated with ethanol and after drying, resuspended in $10 \mathrm{mM}$ Tris, $1 \mathrm{mM}$ EDTA and formamide loading buffer, which were subjected to electrophoresis on a $6 \%$ polyacrylamide gel. DNA sequencing reactions were carried out with the same primer, and the sequencing products were electrophoresed under the same condition. The autoradiography was used to visualize the products.

\section{RESULTS}

\section{Cloning and nucleotide sequence of the groESL locus of $T$. halophila}

To identify the groESL locus of T. halophila JCM5888, PCR-based approach was used. Two oligonucleotide primers for degenerative PCR, groel-TS1 and groel-TA1 (Table 1), were constructed based on the amino acid sequence alignment of highly conserved regions of GroEL proteins from Lactococcus lactis (Kim and Batt, 1993), Lactobacillus zeae (Murphy and Chassy, 1997) and Bacillus subtilis (Li and Wong, 1992). Amplified 900-bp fragment as expected size was cloned into E. coli JM109 using pUC18 and sequenced. The nucleotide sequence of the cloned PCR fragment showed high similarities to other bacterial groEL homologues. This PCR fragment was labeled and used as a probe for Southern hybridization with chromosomal DNA of T. halophila JCM5888. The 1.5-kb and 1.3-kb HindIII digested fragments were strongly hybridized with the probe and cloned into pUC18 vecter. The complete nucleotide sequence of 2,853-bp revealed the presence of two open reading frames (ORFs) encoding putative GroES and GroEL, separated by a $60 \mathrm{bp}$ (Fig. 2). Two putative Shine-Dargano sequences 


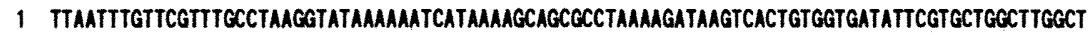
91 CGTTGGCGCAAAGATgGGCGCAAAAAAAGCAATAATATACATAAAAATEGTTAATAAACTATATTTTCTAACAGACATTAGCGACTCCTT 181 TTСТАAGAAATTTTTTTATCAATTTATTTATTATACAAAAAGAGAGTCAGATTGACAATTGCCAGTCATTTAGCCG TAGGTTCGGCTT

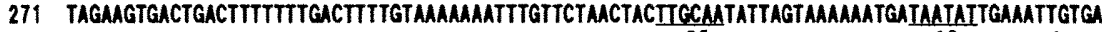

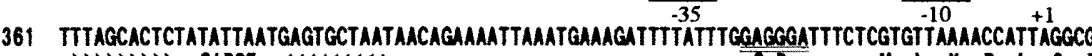

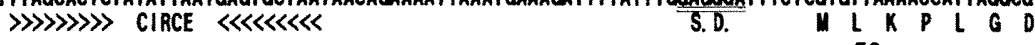
groEs

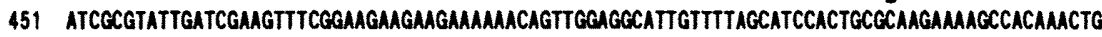
\& V L I E V S E E E E K T V G G I V L A S T A Q E K P Q T G GTAAGGTTGTAGCTGTCGGTCCAGGACGTACACTAGATAATGGTGACTAGCAACCGTTCCTGTAAACGTCGGAGATACTGTTTTATTTO $K$ V V A Y G P G R T L D N G E L A T V P V N V G D T V L F E 631 MAAGTATGCCGGCTCTGAaGTGAAATATGATGGACAAGACTACATGATCTITTCAGCAAAAGACCTTGTAGCAATTGTAGAATAAAAAT $K$ Y $A G$ S E Y K Y $D$ G O $D$ Y

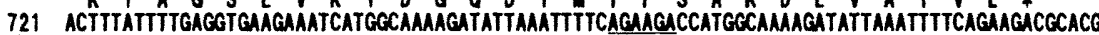
S.D.

811 TCGTTCAATCCTTAATGGCGTAAGTAAATTAGCAGATACAGTCAAAGTAACTTIAGGCCCAAGAGGTCGTAACGTTGTCTTAGAAAATC R S L L G Y S K L A D T V K V T L G P R G R $N Y V$ V L E K $S$

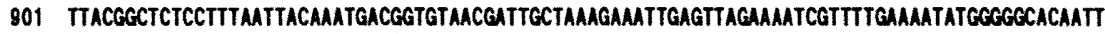
Y G S P L I T N D G V T I A K E I E L E N R F E N W G A Q L 991 AGTTTCAGAAGTTGCTTCTAAACTAACGATATCGCTGGTGACGGTACACAACTECCACTGTATTAGCACAATCTATTGTAMGACGT V S E V A S K T N D I A G D G T T T A T V L A O S I V K N V

1081 TACTTCTGGCGCTAATCCTTTAGGTATTCGTCGTGGTATTGAACAGCAMCACAMAMGCTGTAGMAGATTACMAMTATTTCTACACC

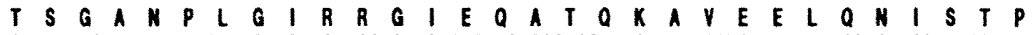

1171 AgtAgATCAAAAGAGCGATTGTACAAGTTGGTGAGTTTCTTCAGGCAGCAAACAGTAGGTCAATATATTGCAGATGCAATGGATAA $V$ E S K E A I V O V G E Y S S G S K O Y G O Y I A D A I D K

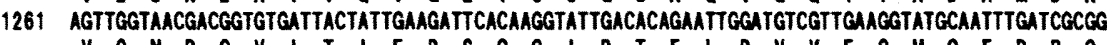
$V G N D C G$ I

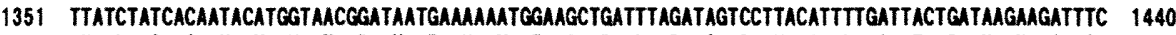
$Y$ Y L S O F

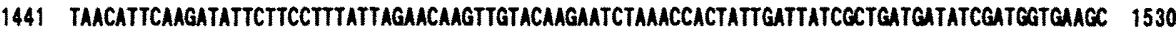
N I O D I L P L L E Q V V O E S K P L L I I I A D

1531 TTTACCAACACTTGTTTTGAATAAAATTCGTGGAACATTTAACGTTGTTGCAACTAAAGCTCCTGGATTTGGCGGCCGTCGTAAAGCAAT 1620

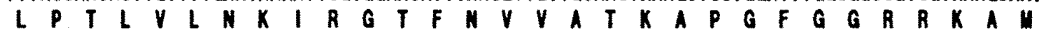

1621 GTtAGAAGACATCGCTGTATTGACTGGTGCTACAGTTATCACTGAMGATTTAGGACTTGACTAAAAGATGCTACAATGGACTCTCTTGG L E

1711 TAAAGCTAATAMAGTAMCTGTTGATAAGGACAATACACAATTGTTGAGGTGCTGGCGTTCAACAGCTATCGAGGTCGTGTACAATT $K$ A N K V T Y D K D N T T I V E G A G D S T A I E D A V O

1801 AATTAAMACCAAGTAGCTGAAACAACTTCTGACTTTGATCGTGAAAAATACAAGACGCCTTCCTAAATTAGCAGGTGGGGTTGCAGT 1890 I K N O V A E T T S D F D R E K L O E R L A K L A G G Y A V

1891 AATCAAAGTTGGTGCCGCTACTGAAACTGACGTACCGAAACTAAAACTACGTATTGAAGATGCTTTAAACGCTECTCGCGCTGGTGTTGA 1980 I K V G A A T E T E Y P K L K L R I E D A L N A A R A G V E

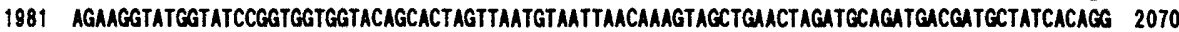
E G I V S G G G T A L Y N V I N K V A E L D A D D

2071 AgTtAACATCGTACTTCGTGCATTAGAMGAACCGGTACGTCAAATCTCTGAAACCCTCGTTTGGAGGATCAGTTATTATTGAMAAACT 2160 V N I V L R A L E E P V R O I S E N A G F E G S V I I E K L

2161 AAAAAGCGAAAAATTAGGAATTGGTTTTAACGCAGCAACTGGTCAATGGGTAACATGGTTGATGCAGGTATTGTTGACCCAACTAAAGT 2250 K S E K L G I G F N A A T G O V V N W V D A G I V D P I K V

2251 TGTACGTTCTGCTTTACAAAATGCAGCATCTATCTCTGCACTATTACTGTCAACAGAAGCAGTAATTCCAGATCGTCCAGATGAATCAGg 2340 V R S A L O N A A S I S A L L L S T E A V I A D R P D E S G

2341 CAATGATGCTGgaGtGGCCCTCAAGGAATGGATCCATCAATGATGGGCGGCGGCATGATGTAATAACTTTACAAAAAGCCTTGGACTTTA 2430 N D A G V A L K E V I H Q *

2431 AAATGTCCAAGGCTITTTTGCTGTGAATCGAAGCGTAAACAAAGAGATGACAGTACTAGGGCGAGCGAAGGCGGCCGTAGTGTCCTTT 2520 «

2521 ACCTTTTATCGTTGATAATACAAAGAGCTATGCGATTCGAATTGCTATATATTCAACATAGAAATTCCATTTCCATGTGCTATCGTCG 2610 2611 TTCATACAACATAAGTTTTCCATTTCCATGTGCTATCGTCGTTCATACAACATAAGTTTTCCATTTCTATGTGCTATCGTTGCTCATACA 2700

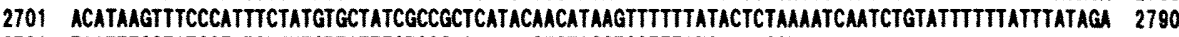
2791 TAАTTТССТАТGCTATCTTTTGTTATTTGTCCCAATTTTTCTCTAGCTCCTTTATCATAAGCT

Fig. 2. Nucleotide and amino acid sequences of the T. halophila groESL operon.

The deduced amino acid sequences of GroES and GroEL are shown below the nucleotide sequence. The hexamers indicative of promoters $(-35$ and -10$)$ are underlined. The inverted repeat sequences including CIRCE element and potential Shine-Dargano sequence (S. D.) are indicated by arrowheads and double underlined, respectively. 
were found, one (GAGGGA) was upstream of groES and the other (AGAAGA) was upstream of groEL gene. An inverted repeat sequence (5'-TTAGCACTC-- $\mathrm{N}_{9}-$ GAGTGCTAA-3') was identified in front of groES. The sequence corresponds to the regulatory sequence of CIRCE, which is involved in the negative regulation of dnaK and groESL operon in numerous Gram-positive bacteria. Immediately downstrcam of the groEL, stem-loop structure, which may be a rho-independent transcription terminator was found, which had a free energy of $-25.8 \mathrm{kcal}^{\mathrm{mol}}{ }^{-1}$.

\section{Analysis of the deduced amino acid sequence of the $T$. halophila groESL operon}

The deduced amino acid sequence of $T$. halophila groES indicated that the gene encoded 95-aa in length and the calculated molecular mass was $10,153 \mathrm{Da}$ (Fig. 2). T. halophila GroES showed high similarities with the GroES proteins of L. lactis, L. zeae and $L$. helveticus $(68 \%, 49 \%$ and $48 \%$ identical, respectively). T. halophila groEL encoded 535-aa residues in a length with a mass of 56,893 Da (Fig. 2). T. halophila GroEL also showed high similarities with the GroEL proteins of those Gram-positive bacteria $(78 \%, 72 \%$ and $68 \%$ identical, respectively). To assess the evolutionary relationship of the cloned T. halophila GroEL, phylogenetic tree of 15 bacterial GroEL homologues was constructed as described in Materials and Methods (Fig. 3). Phylogenetic analysis clearly showed that T. halophila GroEL belongs to the LAB cluster, closely related to L. helveticus and L. johnsonii, and separated from L. lactis.

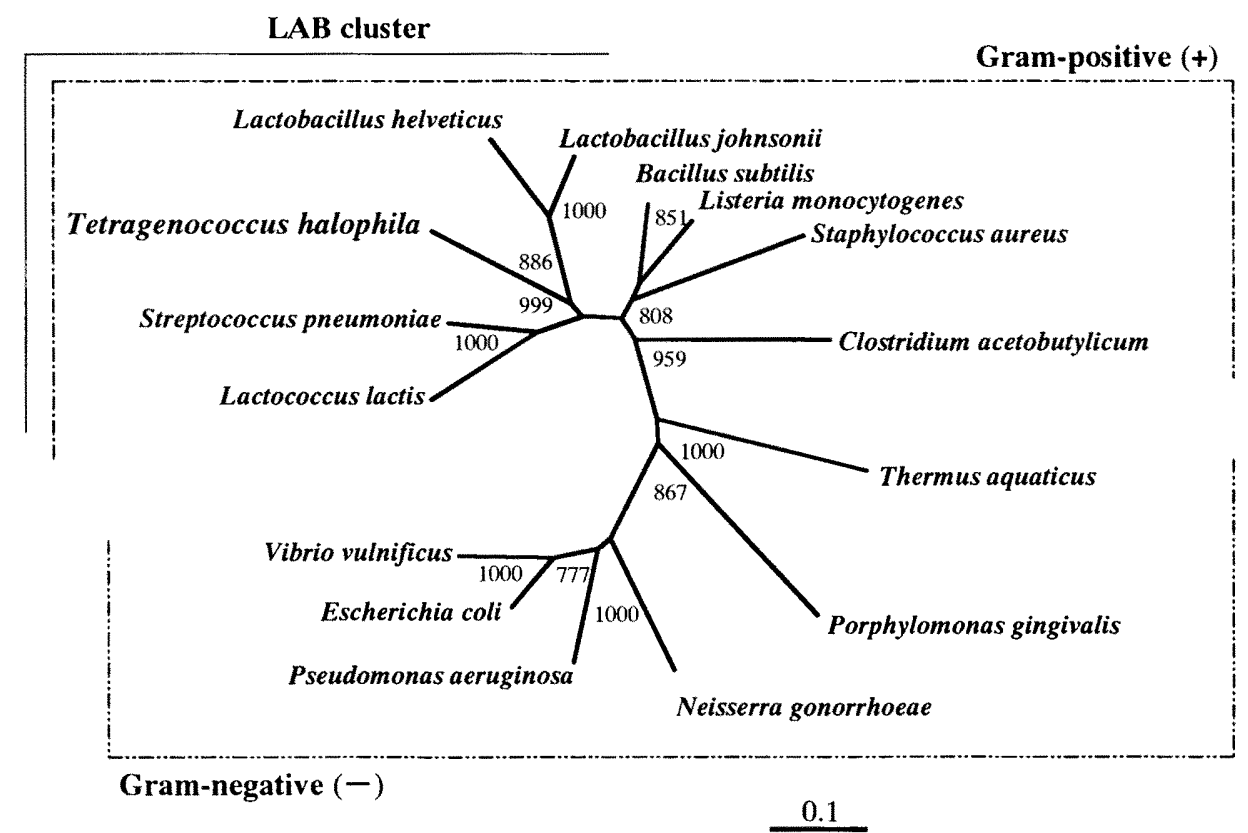

Fig. 3. Phylogenetic analysis of $T$. halophila GroEL and other bacterial GroHL (Hsp60) homologues. A phylogenetic tree was constructed based on the NJ method as described in Materials and Methods. 


\section{Heat shock induction of the T. halophila groESL operon}

Northern blot hybridization was performed with 900-bp groEL probe to clarify the organization and the expression behavior of the T. halophila groESL operon (Fig. 4). The autoradiograph using groEL probe revealed a $2.2-\mathrm{kb}$ transcript. The size of $2.2-\mathrm{kb}$ mRNA could comprise the whole groESL operon, indicating that in T. halophila, groES and groEL are transcribed as a bicistronic operon. Moreover, the amount of $2.2-\mathrm{kb}$ groESL mRNA was increased 3.8-fold upon $30 \mathrm{~min}$ heat shock at $45^{\circ} \mathrm{C}$. This data suggested that cloned T. halophila groESL surely belongs to a system of heat shock response.

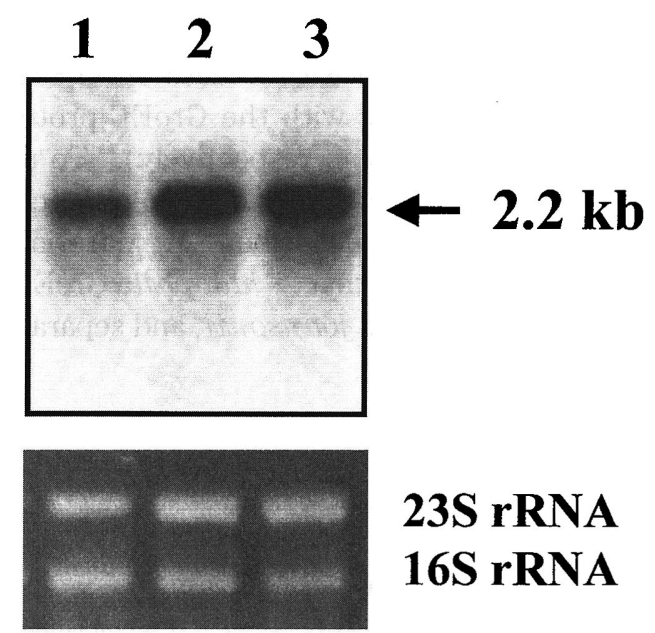

Fig. 4. Northern blot analysis of groEL gene expression in T. halophila.

Each total RNA was isolated from the cells grown at $30^{\circ} \mathrm{C}$ for $24 \mathrm{~h}$ in MRS medium containing $1 \mathrm{M} \mathrm{NaCl}$ (lane 1 ) and further incubated for 10 and $30 \mathrm{~min}$ after shifting to $45^{\circ} \mathrm{C}$ (lanes 2 and 3). Ethidium bromide staining of the gel shows that equal amounts of RNA were loaded.

\section{Salt stress induction of the T. halophila groESL}

In addition to heat shock, we analyzed the effect of high salinity on the transcriptional induction of $T$. halophila groESL by slot-blot hybridization (Fig. 5). The cells grown in the presence of $1.0 \mathrm{M} \mathrm{NaCl}$ for $24 \mathrm{~h}$ were transferred to the same fresh medium containing the indicated $\mathrm{NaCl}$ concentrations, and incubated for further $1 \mathrm{~h}$. Figure 5 indicates the amount of groESL mRNA increased about 4-fold with 3-4 M NaCl, the concentration of which may be critical for cell growth. This indicated that the salt induction of $T$. 


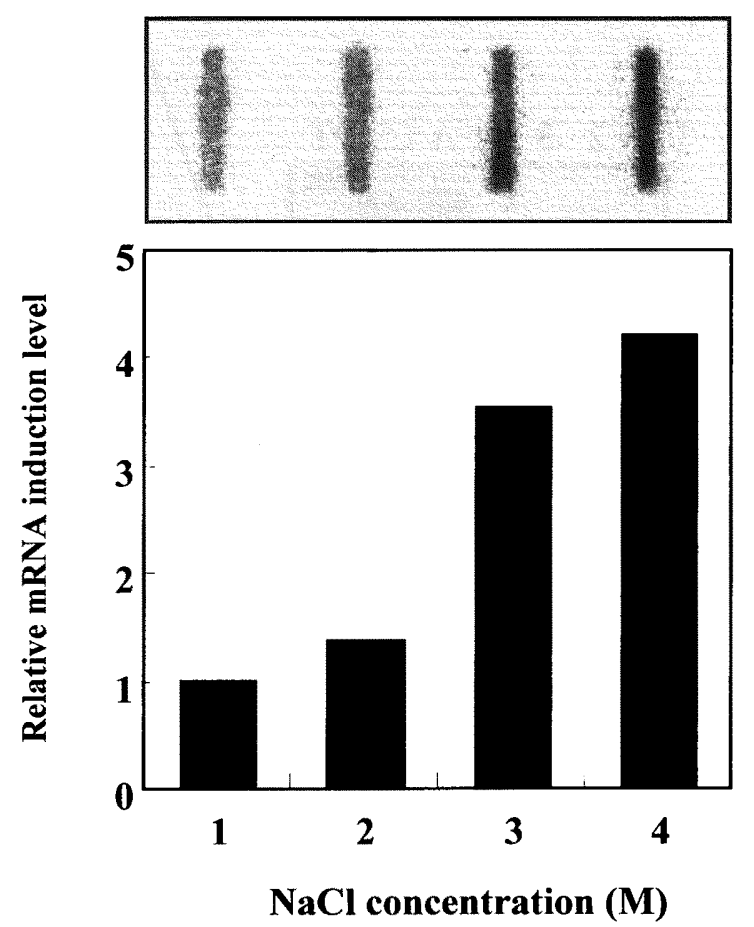

Fig. 5. Transcription of $T$. halophila groESL gene under $\mathrm{NaCl}$ stress.

Transcript levels were quantified using the groEL probe by slot-blot analysis. The cells were grown at $30^{\circ} \mathrm{C}$ for $24 \mathrm{~h}$ in MRS medium containing $1 \mathrm{M} \mathrm{NaCl}$. Each total RNA was obtained from cells after transfer to the fresh MRS medium containing the indicated concentrations of $\mathrm{NaCl}$ and $1 \mathrm{~h}$ of incubation. The signal intensity with $1 \mathrm{M} \mathrm{NaCl}$ was defined as 1.0 .

halophila groESL is also regulated at the transcriptional level.

\section{Identification of the transcriptional initiation site of the $T$. halophila groESL mRNA.}

The transcriptional initiation site of the groESL operon was determined by primer extension analysis. The results with primer PE10 are shown in Fig. 6. The transcription started at T located 76-bases upstream of the start codon of groES, and was induced by heat shock. The B. subtilis $\sigma^{\wedge}$ like promoter (Fujita and Sadaie, 1998) was identified upstream of CIRCE element (with a -35 sequence, 5'-TTGCAA-3', and -10 sequence, 5'--TAATAT-3') (Fig. 2). These data suggested that the expression of T. halophila groESL operon was governed by this constitutive promoter. Moreover, under the heat shock $\left(45^{\circ} \mathrm{C}\right)$ and the salinity $(4 \mathrm{M} \mathrm{NaCl})$ conditions, the T. halophila groESL utilized the 


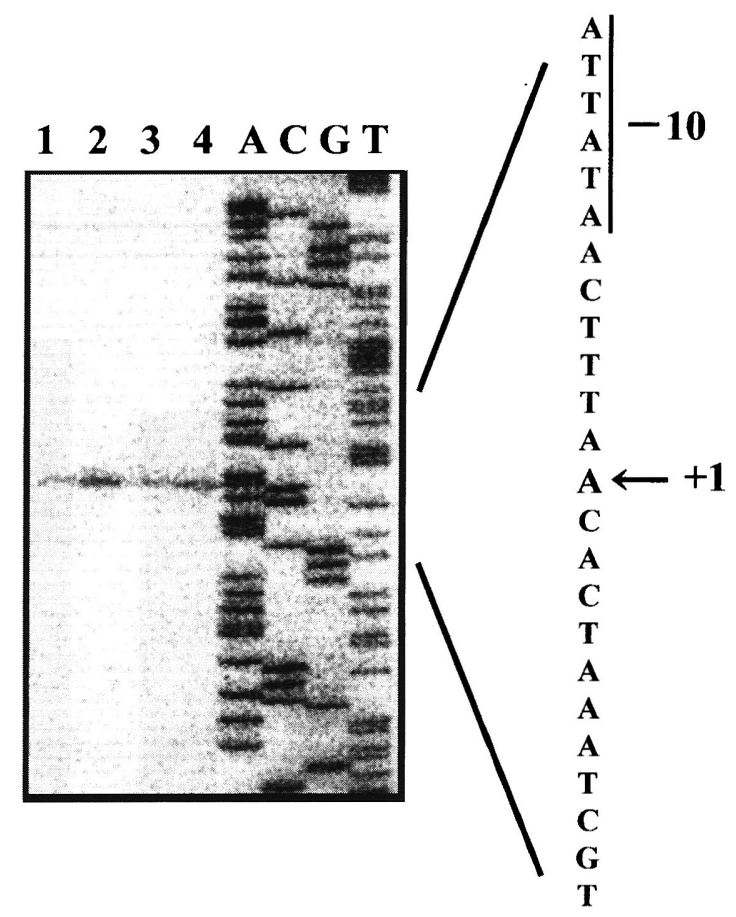

Fig. 6. Determination of the transcriptional initiation site of groESL operon by primer extension analysis.

Lanes A, C, G and T indicate the dideoxy termination lanes. Extension products were generated with total RNA isolated from the cells under normal (lane 1 and 3 , $30^{\circ} \mathrm{C}, 1 \mathrm{M} \mathrm{NaCl}$ ), heat shocked (lane $2,45^{\circ} \mathrm{C}, 10 \mathrm{~min}$ ), and high salinity (lane $4,4 \mathrm{M} \mathrm{NaCl}$ ) conditions as described in the legends of Figs. 4 and 5.

same transcriptional initiation site. This indicated that the T. halophila groESL used a unique promoter even exposed to the environmental stresses.

\section{DISCUSSION}

In this paper, we describe the cloning and nucleotide sequence of groESL operon of the halophilic LAB T. halophila JCM5888, as well as the expression analysis of mRNA level. In our knowledge, this is the first report about the genetic characterization of groESL operon from moderately halophilic eubacteria. The nucleotide sequence of 2,853-bp revealed that the cloned fragments contained two ORFs bearing significant homology to numerous bacterial GroES and GroEL proteins (Fig. 2). A highly conserved inverted repeat sequence, termed CIRCE element, was found in the upstream of groES start codon. This element is extensively studied in B. subtilis (Zuber and Schumann, 
1994) and $S$. aureus (Ohta et al., 1996). We have previously characterized the $h r c A$ gene on the T. halophila chromosomal DNA (Fukuda et al., 2001). It can seem that in $T$. halophila the CIRCE element and HrcA protein also represent an important system to regulate the expression of $T$. halophila groESL operon.

Recently, GroEL (Hsp60) homologues have been used for determining bacterial deep relationship because of the ubiquity and the high degree of sequence conservation (Kwok et al., 1999; Goh et al., 1996). Phylogenetic analysis clearly showed that the GroEL homologues of LAB formed a well-defined subgroup among the Gram-positive cluster. $T$. halophila GroEL was closely related to Lactobacillus species subcluster and separated from $L$. lactis (Fig. 3 ). This result corresponded to the previous taxonomic analysis based on $16 \mathrm{~S}$ rDNA sequence (Collins et al., 1990). The data also suggested that the GroEL homologues could be use as DNA target for species-specific identification of LAB.

Northern blot hybridization analysis has revealed that the groES and groEL genes in T. halophila are transcribed as a bicistronic operon, similar to those found other species of bacteria. The size of groESL mRNA was $2.2-\mathrm{kb}$ in length (Fig. 4). This corresponded to the size from determined transcriptional initiation site of groESL operon to its own rho-independent terminator (Fig. 2). The amount of groESL mRNA was increased about 3.8-fold upon heat shock. The data suggested that the induction of T. halophila groESL by heat shock was regulated at the transcriptional level like other genus of bacteria. Slot-blot analysis of total RNA confirmed that the transcription of T. halophila groESL was induced by high concentration of $\mathrm{NaCl}$ (Fig. 5). The increased expression of groESL represents that GroESL acts as an important factor in $T$. halophila to adapt to environmental high salinity condition. Primer extension analysis determined a unique transcriptional initiation site of groESL operon, preceded by vegetative $B$. subtilis $\sigma^{\mathrm{A}}$ like promoter. The transcriptional initiation site of groESL did not change under the stress condition tested (Fig. 6). Since the site was utilized under both normal and the stress (heat shock, high salinity) conditions, we can conclude that overexpression of $T$. halophila groESL operon against environmental stresses is governed by the interaction of HrcA protein and CIRCE element.

The molecular chaperone DnaK1 from halotolerant cyanobacterium Aphanothece halophytica showed the chaperone activity at 1.0 M NaCl (Hibino et al., 1999). T. halophila can grow under higher external salinity condition than A. halophytica (Rölling et $a l ., 1996)$, so the functional chaperone activity of T. halophila GroESL is of great interest. We are now investigating the ATPase and refolding activity of GroESL protein of T. halophila under high salinity condition. The halotolerant molecular chaperone, which possesses strong folding activity of denatured protein under high salinity might be useful for molecular biological application.

\section{ACKNOWLEDGEMENT}

This work was partly supported by the Sasakawa Scientific Research Grant from The Japan Science Society.

\section{REFERENCES}

Altschul, S. F., T. L. Madden, A. A. Schäffer, J. Zhang, Z. Zhang, W. Miller, and D. J. Lipman 1997 
Gapped BLAST and PSI-BLAST: a new generation of protein database search programs. Nucl. Acids Res., 25: 3389-3402

Asubel, F. M., R. Brent, R. E. Kingston, D. D. Moore, J. G. Seidman, J. A. Smith, and K. Struhl 1987 Current Protocols in Molecular Microbiology. Wiley, NY

Berns, K. I. and C. A. Thomas JR 1965 Isolation of high molecular weight DNA from Haemophilus influenzae. J. Mol. Biol., 11: 476-490

Broadbent, J. R., C. J. Oberg, and L. Wei 1998 Characterization of the Lactobacillus helveticus groESL operon. Res. Microbiol., 149: 247-253

Collins, M. D., A. M. Williams, and S. Wallbanks 1990 The phylogeny of Aerococcus and Pediococcus as determined by $16 \mathrm{~S}$ rRNA sequence analysis; description of Tetragenooccus gen. nov.. FEMS Microbiol. Lett., 70: 255-262

Cowing, D. W., J. C. A. Bardwell, E. A. Craig, C. Woolford, R. W. Hendrix, and C. A. Gross 1985 Consensus sequence for Escherichia coli heat shock gene promoters. Proc. Natl. Acad. Sci. USA, 82: $2679-2683$

Fujita, M., A. Amemura, and H. Aramaki 1998 Transcription of the groESL operon in Pseudomonas aeruginosa PAO1. FEMS Microbiol. Lett., 163: 237-242

Fujita, M. and Y. Sadaie 1998 Promoter selectivity of the Bacillus subtilis RNA polymerase sigmaA and sigmaH holoenzymes. J. Biochem., 124: 89-97

Fukuda, D., M. Watanabe, S. Sonezaki, K. Sonomoto, and A. Ishizaki 2001 Characterization and expression analysis of $d n a K$-operon from halophilic lactic acid bacterium Tetragenococcus halophila., In Proceedings of the 101th General Meeting of the American Society for Microbiology 2001, American Society for Microbiology, Washington, D. C., pp. 450-451

Gahan, C. G., J. O' Mahony, and C. Hill 2001 Characterization of the groESL operon in Listeria monocytogenes: utilization of two reporter systems ( $q f p$ and $h l y)$ for evaluating in vivo expression. Infect. Immun., 69: 3924-393

Goh, S. H., S. Potter, J. O. Wood, S. M. Hemmingsen, R. P. Reynolds, and A. W. Chow 1996 HSP60 gene sequences as universal targets for microbial species identification: studies with coagulase-negative staphylococci. J. Clin. Microbiol., 34: 818-23

Gross, C. A., D. B. Strauss, J. W. Erickson, and T. Yura 1990 The function and regulation of heat shock proteins in Escherichia coli. In: Morimoto, R. I., A. Tissieres, and C. Georgopoulos, Stress Proteins in Biology and Medicine, eds. Cold Spring Harbor Laboratory Press, Cold Spring Harbor, NY, pp. 167-189

Hartl, F. -U. 1996 Molecular chaperones in cellular protein folding. Nature, 381: 571-580

Hemmingsen, S. M., C. Woolford, S. M. van der Vies, K. Tilly, D.T. Dennis, C. P. Georgopoulos, R.W. Hendrix, and R. J. Ellis 1988 Homologous plant and bacterial proteins chaperone oligomeric protein assembly. Nature, 333: 330-334

Hibino, T., N. Kaku, H. Yoshikawa, T. Takabe, and T. Takabe 1999 Molecular characterization of DnaK from the halotolerant cyanobacterium Aphanothece halophytica for ATPase, protein folding, and copper binding under various salinity conditions. Plant Mol. Biol., 40: 409-418

Homuth, G., S. Domm, D. Kleiner, and W. Shumann 2000 Transcriptional analysis of major heat shock genes of Helicobacter pylori. J. Bacteriol., 182: 4257-4263

Hotokezaka, H., H. Hayashida, N. Ohara, H. Nomaguchi, K. Kobayashi, and T. Yamada 1994 Cloning and sequencing of the groESL homologue from Porphyromonas gingivalis. Biochim. Biophys. Acta, 1219: $175-178$

Innis, M. A., D. H. Gelfand, J. J. Sninsky, and T. W. White 1990 PCR Protocols. Academic Press, Inc., San Diego, CA

Kilstrup, M., S. Jacobsen, K. Hammer, and F. K. Vogensen 1997 Induction of heat shock proteins DnaK, GroEL, and GroES by salt stress in Lactococcus lactis. Appl. Environ. Microbiol., 63: 1826-1837

Kim, G. S. and C. A. Batt 1993 Cloning and sequencing of the groEL operon in Lactococcus lactis subsp. lactis. Gene, 127: 121-126

Kim, S. N., S. W. Kim, S. N. Pyo, and D. K. Rhee 2001 Molecular cloning and characterization of groESL operon in Streptococcus pneumoniae. Mol. Cells, 30,360-368

Kwok, A. Y., S. C. Su, R. P. Reynolds, S. J. Bay, Y. Av-Gay, N. J. Dovichi, and A. W. Chow 1999 Species identification and phylogenetic relationships based on partial HSP60 gene sequences within the genus Staphylococcus. Int. J. Syst. Bacteriol., 49: 1181-1192

Langer, T., G. Pfeifer, J. Martin, W. Baumeister, and F. -U. Hartl 1992 Chaperonin-mediated protein 
folding: GroES binds to one end of the GroEL cylinder, which accommodates the protein substrate within its central cavity. EMBO J., 11: $4757-4765$

Li, M. and S. - L. Wong 1992 Cloning and characterization of the groESL operon from Bacillus subtilis. J. Bacteriol., 174: 3981-3992

Liberek, K., J. Marszalek, D. Ang, C. Geogopoulos and M. Zylicz 1991 Escherichia coli DnaJ and GrpE heat shock proteins interact both in vivo and in vitro. J. Bacteriol., 171: 1590-1596

Lindquist, S. and E. A. Craig 1988 The heat-shock proteins. Annu. Rev. Genet., 22: 631-677

Marmur, J. 1961 A procedure for the isolation of deoxyribonucleic acid from microorganisms. J. Mol. Biol., 3: 208-218

Mikulik, K. and O. Benada 1993 GroEL-like protein complex of thermophilic bacterium Thermus aquaticus. Biochem. Biophys. Res. Commun., 15: 716-721

Murphy, C. M. and B. M. Chassy 1997 Molecular characterization of the heat-shock regulated groESL operon of Lactobacillus zeae. Unpublished, Genbank accession number AF010281

Narberhaus, F. and H. Bahl, 1992 Cloning, sequencing, and molecular analysis of the groESL operon of Clostridium acetobutylicum. J. Bacteriol., 174: 3282-3289

Ohta, T., K. Honda, M. Kuroda, K. Saito, and H. Hayashi 1993 Molecular characterization of the gene operon of hear shock proteins HSP60 and HSP10 in methicillin-resistant Staphylococcus aureus. Cellul. Mol. Biol. Res., 193: 730-737

Ohta, T., S. Nettikadan, F. Tokumasu, H. Ideno, Y. Abe, M. Kuroda, H. Hayashi, and K. Takeyasu 1996 Atomic force microscopy proposes a novel model for stem-loop structure that binds a heat shock protein in the Staphylococcus aureus HSP70 operon, Biochem. Biophys. Res. Commun., 226: $730-734$

Robert, H., C. L. Marrec, C. Branco, and M. Jebbar 2000 Glycine betaine, carnitine, and choline enhance salinity tolerance and prevent the accumulation of sodium to a level inhibiting growth of Tetragnococcus halophila. Appl. Environ. Microbiol., 66: 509-517

Röling, W. F. and H. W. Van Verserveld 1996 Characterization of Tetragenococcus halophila populations in Indonesian soy mash (Kecap) fermentation. Appl. Environ. Microbiol., 62: 1203-1207

Saitou, N. and M. Nei, 1985 The neighbor-joining method, a new method for reconstructing phylogenetic trees. Mol. Biol. Evol., 4: 406-425

Sambrook, J., E. F. Fritsch, and T. Maniatis 1989 Molecular Cloning: A Laboratory Manual, 2nd ed. Cold Spring Harbor Laboratory, Cold Spring Harbor, NY

Sipos, A., M. Klocke, and M. Frosch 1991 Cloning and sequencing of the genus coding or the 10- and 60-kDa heat shock proteins from Pseudomonas aeruginosa and mapping of a species $\sim$ specific epitope. Infect. Immun., 59: 3219-3226

Tauschek, M., C. W. Hamilton, L. A., Hall, C. Chomvarin, J. A. Fyfe, and J. K. Davies 1997 Transcriptional analysis of the groESL operon of Neisseria gonorrhoeae. Gene, 189: 107-112

Thompson, J. D., D. G. Higgins, and T. J. Gibson 1994 CLUSTALW: improving the sensitivity of progressive multiple sequence alignment through sequence weighting, positions-specific gap penalties and weight matrix choice. Nucl. Acids Res., 22: 4673-4680

Walker, D. C., H. S. Girgis, and T. R. Klaenhammer 1999 The groESL chaperone operon of Lactobacillus johnsonii. Appl. Environ. Microbiol., 65: 3033-3041

Wong, H. -C. and K. -H. Lu 2001 Unpublished, Genbank accession number; AY017169

Zuber, U. and W. Schumann 1994 CIRCE, a novel heat shock element involved in regulation of heat shock operon dnaK of Bacillus subtilis. J. Bacteriol., 176: 1359-1369 